\title{
Nonsteroidal anti-inflammatory drugs affect the mammary epithelial barrier during inflammation
}

\author{
G. F. Sintes, R. M. Bruckmaier, (1) and O. Wellnitz* (1) \\ Veterinary Physiology, Vetsuisse Faculty, University of Bern, 3001 Bern, Switzerland
}

\begin{abstract}
During inflammation of the mammary gland, the blood-milk barrier, which is predominantly composed of mammary epithelial cells, loses its integrity and gradients between blood and milk cannot be maintained. Nonsteroidal anti-inflammatory drugs (NSAID) are commonly used systemically in combination with local administration of antimicrobials in mastitis treatments of dairy cows to improve the well-being of the cow during the disease. However, the knowledge about their effects on the blood-milk barrier is low. This study aimed to investigate effects of different NSAID, with different selectivity of cyclooxygenase-inhibition, on the transepithelial electrical resistance (TEER) and capacitance, cell viability, and expression of tumor necrosis factor $\alpha$ of bovine mammary epithelial barriers in vitro. Primary mammary epithelial cells of 3 different cows were challenged with lipopolysaccharide (LPS) from Escherichia coli with or without addition of ketoprofen $(1.25 \mathrm{mg} / \mathrm{mL}$ or $4 \mathrm{mM})$, flunixin meglumine $(1.0 \mathrm{mg} /$ $\mathrm{mL}$ or $4 \mathrm{mM})$, meloxicam $(0.25 \mathrm{mg} / \mathrm{mL}, 0.75 \mathrm{mg} / \mathrm{mL}$, or $4 \mathrm{mM})$, diclofenac $(0.75 \mathrm{mg} / \mathrm{mL}$ or $4 \mathrm{mM})$ or celecoxib $(0.05 \mathrm{mg} / \mathrm{mL})$ for $6 \mathrm{~h}$. Concentrations were adapted to comparable relations of the recommended dosage for systemic application. Additionally, a similar molar concentration of all NSAID was used. Lipopolysaccharide with or without NSAID induced a decrease in TEER within $5 \mathrm{~h}$, which returned to control level within 14 h. Viability of cells challenged with LPS only was not affected. However, the cell viability was decreased with increasing concentrations of NSAID and this effect was amplified with simultaneous LPS challenge. Ketoprofen at both dosages, flunixin meglumine at $1.0 \mathrm{mg} / \mathrm{mL}$, and meloxicam at $0.75 \mathrm{mg} / \mathrm{mL}$ accelerated the recovery of TEER in comparison to LPS only (return to control level within $9 \mathrm{~h}$ ). The comparison of NSAID effects at the same molecular quantity of $4 \mathrm{~m} M$ showed different effect on the barrier in which ketoprofen accelerated the
\end{abstract}

Received May 1, 2020.

Accepted June 25, 2020.

*Corresponding author: olga.wellnitz@vetsuisse.unibe.ch recovery after LPS-induced barrier opening, whereas meloxicam and diclofenac slowed down the recovery (return to control level after $24 \mathrm{~h}$ ). In conclusion, NSAID do not prevent the mammary epithelial barrier opening by LPS; however, ketoprofen, flunixin meglumine, and meloxicam obviously support the re-establishment of the barrier integrity. Used in mastitis therapy at an optimized dosage the tested NSAID would likely support the recovery of milk composition. However, an overdose of NSAID would likely cause tissue irritation and in turn, a delayed recovery of the barrier permeability.

Key words: blood-milk barrier, nonsteroidal antiinflammatory drugs, mastitis

\section{INTRODUCTION}

Mastitis treatment in dairy cows mostly involves local application of antibiotics. This medication is increasingly combined with a systemic administration of anti-inflammatory substances such as nonsteroidal anti-inflammatory drugs (NSAID; Kayitsinga et al., 2017). These improve the general condition of cows by reducing pain and inflammation (Banting et al., 2008). The NSAID are competitive inhibitors of cyclooxygenases (COX), which are key enzymes for the formation of prostaglandins (Llorens et al., 2002). Different COX isoforms exist: COX-1 is responsible for a constant prostaglandin production, which has a homeostatic role, and COX-2 is inducible and catalyzes prostaglandin synthesis during inflammation. The COX-2 selectivity is a novelty to fight against side effects from NSAID, such as gastro-intestinal disorders (Kawada et al., 2012). Besides COX inhibition, NSAID have been shown to act through other mechanisms such as the inhibition of nuclear factor- $\kappa \mathrm{B}$, which leads to a reduction of proinflammatory cytokine expression (Diaz-Gonzalez and Sanchez-Madrid, 2015). In dairy cows, several NSAID are used. Ketoprofen and flunixin meglumine are nonselective COX inhibitors. They have been shown to support the cure of mastitis and wellbeing of the animals (Banting et al., 2008; Yeiser et al., 2012). Ketoprofen has been shown to reduce the pro-inflammatory cytokine expression of mammary epi- 
thelial cells (MEC) challenged with LPS (Dan et al., 2018). Diclofenac is also a nonselective COX inhibitor but not recommended for mastitis treatment in dairy cows. At present, the only indication of diclofenac for ruminants is the treatment of pain around castration of lambs (Molony et al., 1997). Meloxicam is a COX-2 selective inhibitor recommended for dairy cow treatment and it was shown to reduce the SCC increase in milk and the risk of culling during and after mastitis (McDougall et al., 2009). In MEC it limits the LPSinduced cytokine expression (Caldeira et al., 2019). Celecoxib is a member of the coxib family, which are, as meloxicam, COX-2 selective NSAID. Celecoxib is used in humans but not recommended for dairy cow treatment or any other animals; however, other members of the coxib family (cimicoxib, firocoxib, mavacoxib, and robenacoxib) are recommended for dogs, cats, and horses. The role of NSAID on the blood-milk barrier and on the expression of pro-inflammatory cytokines during inflammation is barely investigated. Solely an intramammary administration of ketoprofen to cows with experimentally induced mastitis is known to limit the increase of barrier permeability during mastitis (Dan et al., 2018). In contrast, the stabilizing effects of glucocorticoids such as prednisolone on the bloodmilk barrier are well investigated (Wellnitz et al., 2014, Wall et al., 2016) and can, therefore, be used as control treatment for barrier closure.

In the udder tissue, MEC, closely linked by tight junctions, are the main component of the blood-milk barrier (Wellnitz et al., 2016). The integrity of the blood-milk barrier is crucial to maintain gradients of the various constituents in blood and milk as a prerequisite of an adequate milk secretion. During inflammation, the blood-milk barrier loses integrity, which causes an influx of blood constituents into the milk (Wellnitz et al., 2015), and vice versa (Bruckmaier et al., 2004). There is also a directed influx of blood constituents into milk, mainly leukocytes, which represent the major component of the innate immune response in the mammary gland (Burton and Erskine, 2003; Wellnitz and Bruckmaier, 2012; Bruckmaier and Wellnitz, 2017). The culture of primary MEC and the use of a transwell system to measure the transepithelial electrical resistance (TEER) is suitable to investigate the blood-milk barrier opening during an in vitro modeled inflammation using Escherichia coli-derived LPS (Wellnitz et al., 2016). The TEER is inversely proportional to the permeability of the barrier (Berkes et al., 2003) and represents mainly the integrity of tight junctions (Benson et al., 2013). Furthermore, changes of the calculated capacitance from the measured impedance of the cell barrier can indicate changes of cell membrane surface of the single cells (Afshar et al., 2019), and, therefore, allows conclusions on membrane complexity and cell morphology.

The aim of this study was to investigate effects of different NSAID, with different preferences of COX-1 and COX-2 inhibition, on the mammary epithelial barrier in vitro with and without simultaneous immune challenge. Our hypothesis was that NSAID inhibit opening of tight junctions between epithelial cells in response to immune challenge dose dependently. This effect would have an influence on cure rates of dairy cow mastitis if used in vivo.

\section{MATERIALS AND METHODS}

\section{Animals}

Three lactating Holstein cows were randomly selected as cell donors. They had no known history of mastitis and their total milk SCC was less than 100,000 cells/ $\mathrm{mL}$. Mammary tissue was collected within 30 min after slaughter. Isolation and cryopreservation of MEC was performed as described by Wellnitz and Kerr (2004).

\section{Cell Culture and Barrier Formation}

Cells of each cow in passage 2 to 4 were cultured separately in Dulbecco's modified Eagle's medium/F-12 containing $10 \%$ of fetal bovine serum, $500 \mathrm{IU} / \mathrm{mL}$ penicillin, $0.1 \mathrm{mg} / \mathrm{mL}$ streptomycin (Sigma-Aldrich, Buchs, Switzerland), $50 \mathrm{ng} / \mathrm{mL}$ gentamicin (Sigma-Aldrich), $10 \mu \mathrm{g} / \mathrm{mL}$ insulin, $5.5 \mu \mathrm{g} / \mathrm{mL}$ transferrin, and $5 \mathrm{ng} /$ $\mathrm{mL}$ sodium selenite (ITS, Sigma-Aldrich). Once cells reached a confluency of approximately $80 \%$, they were trypsinized and seeded on the apical side of polyester transwell inserts (12-wells, $0.4-\mu \mathrm{m}$ pore, Corning, Corning, NY) at a concentration of $1.5 \times 10^{5}$ cells/insert. Each insert was placed on the CellZscope module (NanoAnalytics, Münster, Germany).

\section{Technique to Measure TEER and Capacitance}

The CellZscope module (NanoAnalytics) is an automated device for measuring the transepithelial impedance of a cell layer grown on a transwell system. By placing an electrode on each side of the membrane, and applying a small alternating current of variable frequency, the frequency-dependent electric impedance can be measured. Provided that the permeability of the membrane support is properly selected, the cell layer is the ion current-limiting entity. Equivalent circuit and corresponding mathematical models can be applied to extract parameters that mirror the barrier properties of the cell layer. In this circuit, the cell layer is represented as a resistance (TEER) and a capacitor (capacitance) 
in series, whereas both the resistance of the medium and capacitance of the electrode-medium interface have to be considered in the mathematical model (Benson et al., 2013). The TEER represents the capacity of the current to flow through the paracellular pathway. The capacitance represents the capacity of current to flow through the transcellular pathway and should be represented as resistance (resistance of the cell membrane) and a capacitor (cell membrane capacitance) in series. At the used frequency range, the very high resistance of the cell membrane causes the current to flow mainly through the capacitor and allows us to summarize the transcellular pathway as a capacitor (Benson et al., 2013). The resulting total impedance of the setup is dominated at low frequencies by the electrode-medium interfaces and at high frequencies by the culture medium. At mid-range frequencies, the TEER and capacitance contribute predominantly to the total impedance, leading to the formation of a plateau. The impedance level (height of this plateau) is determined by TEER and the frequency range (width of the plateau) is determined by the capacitance.

\section{Preparation of LPS and NSAID Solutions}

Ketoprofen (Sigma-Aldrich), flunixin meglumine (Sigma-Aldrich), diclofenac (diclofenac-sodium, reference standard for European pharmacopoeia, Strasbourg, France), celecoxib (reference standard for European pharmacopoeia) and prednisolone (Sigma-Aldrich) were predissolved in $99 \%$ ethanol, whereas meloxicam (meloxicam-sodium salt hydrate, Sigma-Aldrich) was predissolved in double-distilled water using the protocol described by Caldeira et al. (2019). Lipopolysaccharide from E. coli, serotype O26:B6 (Sigma-Aldrich), was directly dissolved in the medium. Drug concentrations were $1.25 \mathrm{mg} / \mathrm{mL}$ medium for ketoprofen, $1.0 \mathrm{mg} / \mathrm{mL}$ medium for flunixin meglumine, $0.25 \mathrm{mg} / \mathrm{mL}$ medium for meloxicam, $0.75 \mathrm{mg} / \mathrm{mL}$ medium for diclofenac and $0.05 \mathrm{mg} / \mathrm{mL}$ medium for celecoxib. The used drug concentrations were adapted to recently optimized concentrations of ketoprofen (Dan et al., 2018) and meloxicam (Caldeira et al., 2019) in MEC culture. Concentrations of the other NSAID were then calculated to comparable ratios to the recommended in vivo dosages as used for ketoprofen and meloxicam. For meloxicam, an additional solution with a concentration of $0.75 \mathrm{mg} / \mathrm{mL}$ was made. To allow comparisons of NSAID effects on an equal molar level, additional solutions at molecule quantity of $4 \mathrm{~m} M$ were established. All solutions were supplemented with the same volume of $99 \%$ ethanol (33 $\mu \mathrm{L} / \mathrm{mL}$ ). Only for diclofenac at $4 \mathrm{~m} M$, more ethanol (53 $\mu \mathrm{L} / \mathrm{mL}$ ) was needed for dissolving. Therefore, an additional control solution with the same supplementation of ethanol was included.

\section{Cell Treatments}

When epithelial cells build a monolayer, TEER reaches a plateau. With continued growth, epithelial cells may grow on top of their neighboring cells, leading to a nonphysiological pseudo-multilayer. This effect has been shown in Caco-2 cells (Srinivasan et al., 2015). Therefore, the various treatments with LPS and NSAID were applied when TEER was at the transition between increase phase and plateau phase. Cells from each cow were challenged separately in duplicates for 6 h (5 measurements). Each treatment with NSAID was performed with and without an additional challenge with LPS at a concentration of $1.0 \mu \mathrm{g} / \mathrm{mL}$ of medium. Thereafter media were replaced by a culture medium without any stimulants. TEER and capacitance were measured every hour from $7 \mathrm{~h}$ before to $30 \mathrm{~h}$ after treatment. Medium only, LPS $(1.0 \mu \mathrm{g} / \mathrm{mL}$ medium $)$ and prednisolone $(1.0 \mu \mathrm{g} / \mathrm{mL}$ medium, with LPS $)$ were used as controls.

\section{Measurement of TNF- $\alpha$ mRNA Abundance}

Cells were cultured as described before and seeded on a 12 -well plate at a concentration of $1 \times 10^{5}$ cells/well. After reaching a confluency of approximately $70 \%$, cells were challenged with flunixin meglumine, diclofenac and celecoxib with or without LPS according to the same protocol as described for the first experiment. After $6 \mathrm{~h}$, the supernatant was aspirated and cells were harvested with $300 \mu \mathrm{L}$ of peqGold Trifast (Peqlab Biotechnologie GmbH, Erlangen, Germany). Total RNA was extracted using Direct-zol RNA MiniPrep (Zymo Research Corp., Irvine, CA), following the instructions of the manufacturer. Total RNA concentration was determined using a NanoDrop 2000 spectrophotometer (Thermo Fisher Scientific Inc., Waltham, MA) at 260 and $280 \mathrm{~nm}$. For cDNA synthesis, $500 \mathrm{ng}$ of total RNA was reverse transcribed using 200 units of Moloney Murine Leukemia Virus Reverse Transcriptase (Promega Corp., Madison, WI) and $100 \mathrm{pmol}$ of random primers (Invitrogen, Leek, the Netherlands). For quantitative real-time PCR a SensiMix SYBR Hi-ROX kit (Quantace, Biolabo, Chatel St. Denis, Switzerland) with a Rotor-Gene 6000 (Corbett Research, Sydney, Australia) was used. The 2 reference genes (GAPDH and ubiquitin) known to be suitable for bovine MEC (Griesbeck-Zilch et al., 2008) were selected. Primers for reference and target genes were commercially synthesized (Microsynth, Balgach, Switzerland) using sequences published before 
(Griesbeck-Zilch et al., 2008). Cycle threshold values (Ct) were calculated with Rotor-Gene software version 1.7.75 (Corbett Research). Target gene Ct values were normalized to the reference genes according to the following equation: $\Delta \mathrm{Ct}=\mathrm{Ct}$ (arithmetic mean of reference genes) - CT (target gene). The reference genes are higher expressed as the target gene resulting in negative values. With the addition of 20 to all $\Delta \mathrm{Ct}$ results, positive numbers are received and a higher value represents a higher mRNA abundance (relative expression).

\section{Cell Viability Measurements}

Mammary epithelial cells from 3 cows were grown in a 96 -well plate $\left(1 \times 10^{4}\right.$ cell/well $)$, and were challenged with LPS, ketoprofen, flunixin meglumine, meloxicam, diclofenac, and celecoxib at the same concentrations as described before. Treatment with ethanol supplemented medium was used as control. After $6 \mathrm{~h}$, cells were washed with $100 \mu \mathrm{L}$ of DMEM/F-12 medium. Each well was filled with $100 \mu \mathrm{L}$ of DMEM/F12 medium with $10 \%$ FBS, $1 \%$ penicillin-streptomycin, $1 \%$ gentamicin, and $1 \%$ ITS, and $20 \mu \mathrm{L}$ of CellTiter $96 \mathrm{AQ}_{\text {ueous }}$ One Solution (Promega, Dübendorf, Switzerland). Absorbance was measured after $2 \mathrm{~h}$ of incubation at $490 \mathrm{~nm}$ using a Synergy Mx microplate reader (BioTek Instruments, Winooski, VT).

\section{Statistical Analyses}

All data analyses were performed using SAS (version 9.4; SAS Institute Inc., Cary, NC). The TEER $(\Omega /$ $\left.\mathrm{cm}^{2}\right)$, capacitance $\left(\mu \mathrm{F} / \mathrm{cm}^{2}\right)$, relative mRNA expression of TNF- $\alpha(\Delta C t)$ and cell viability were used for the analysis. A repeated measurement mixed-model analysis using the MIXED procedure was performed to examine the effects of the different NSAID. For mRNA expression and cell viability, the model included treatment as a fixed effect. For the TEER and capacitance, the data of the various treatment were compared within individual time points $(0,5,10,15,20$, or $30 \mathrm{~h}$ after the challenge), and the model included treatment as a fixed effect. In all analyses, cow was used as the repeated subject. Significance was declared at $P<0.05$, and data are reported as means \pm standard errors of the means.

\section{RESULTS}

\section{TEER and Capacitance}

The TEER of the barrier formed by cells from all cows just before treatment $(0 \mathrm{~h})$ was $1,136 \pm 21 \Omega /$

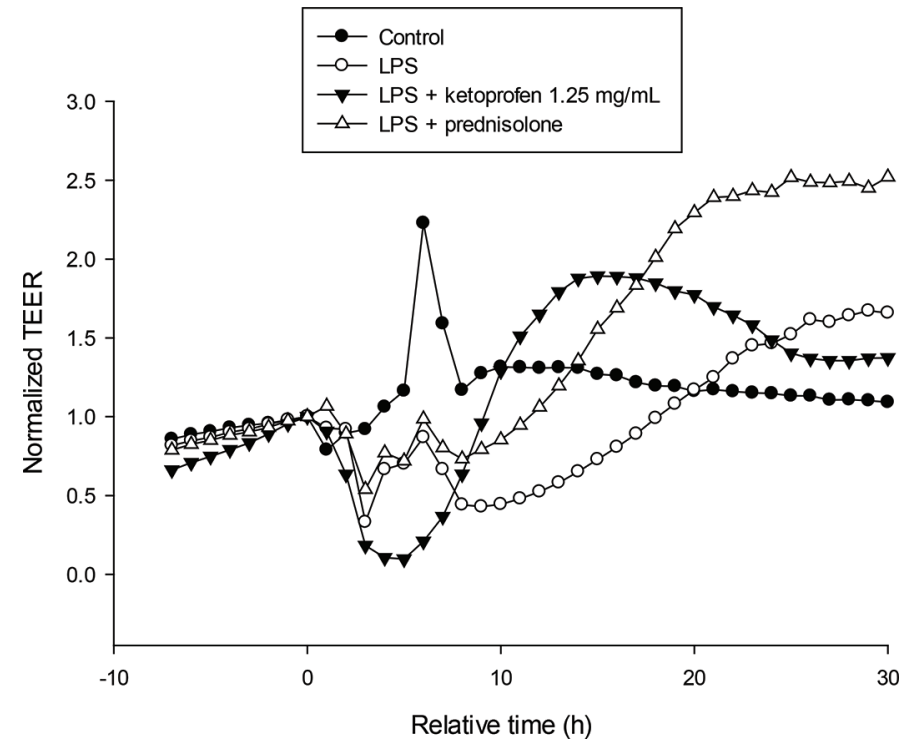

Figure 1. Representative curve for transepithelial electrical resistance (TEER; $\Omega / \mathrm{cm}^{2}$ ) normalized by calculating the ratio relative to the measurement of the control before treatment $(0 \mathrm{~h})$, and cells treated with $1.0 \mu \mathrm{g} / \mathrm{mL}$ LPS with or without $1.25 \mathrm{mg} / \mathrm{mL}$ ketoprofen or $1.0 \mu \mathrm{g} / \mathrm{mL}$ prednisolone during the entire experiment. The $\mathrm{x}$-axis represents the relative time of the experiment starting at $7 \mathrm{~h}$ before challenge. Measurements were performed every hour until $30 \mathrm{~h}$ after challenge.

$\mathrm{cm}^{2}$ and the capacitance was $2.00 \pm 0.04 \mu \mathrm{F} / \mathrm{cm}^{2}$. For data presentation, TEER and capacitance from each well was normalized by calculating the ratio relative to the measurement of the control before treatment $(0$ h). A representative curve for TEER measurement is shown in Figure 1.

Results of treatments without additional LPS challenge with all NSAID at their different concentrations are shown in Figure 2. At $5 \mathrm{~h}$ after treatment with flunixin meglumine and diclofenac at both concentrations and celecoxib, TEER was reduced compared with control $(P<0.0001)$. The capacitance was reduced $(P=$ $0.027,0.015,0.034$, and 0.02 , respectively) with flunixin meglumine at both concentrations, at a high dosage $(4 \mathrm{mM})$ meloxicam, and at a low dosage of diclofenac $(0.75 \mathrm{mg} / \mathrm{mL})$. Celecoxib and meloxicam at low dosages did not reduce the capacitance. Only a high dosage of diclofenac $(4 \mathrm{mM})$ increased the capacitance $(P<$ 0.0001 ) within $5 \mathrm{~h}$ and stayed increased until the end of the experiment after $30 \mathrm{~h}$. In contrast, ketoprofen and meloxicam at all concentrations did not affect TEER $5 \mathrm{~h}$ after treatment. The TEER returned to level of control cells $15 \mathrm{~h}$ after treatment with low dosage of diclofenac. After 15, 20, and $30 \mathrm{~h}$ flunixin meglumine at both concentrations induced higher TEER compared with controls. Furthermore, high dosage of ketoprofen $(1.25 \mathrm{mg} / \mathrm{mL})$ but not the low dosage $(4 \mathrm{mM})$ and 
meloxicam at the intermediary dosage of $0.75 \mathrm{mg} / \mathrm{mL}$ but also not with the high $(4 \mathrm{mM})$ or low dosage $(0.25$ $\mathrm{mg} / \mathrm{mL})$, increased TEER after $10 \mathrm{~h}(P=0.018$ and $<0.0001$, respectively) compared with control cells. In contrast, TEER of cells treated with the high dosage of diclofenac, and with celecoxib did not recover within the entire experiment $(30 \mathrm{~h})$.

Results of NSAID treatment with comparable concentrations based on recommended dosages for in vivo use with additional LPS challenge are shown in Figure 3. The challenge with LPS only reduced TEER at 5,10 , and $15 \mathrm{~h}(P=0.001,<0.0001$, and 0.002 , respectively). This reduction was recovered after $20 \mathrm{~h}$. The capacitance was not significantly affected by LPS throughout the entire experiment $(30 \mathrm{~h})$. At $20 \mathrm{~h}$ and 30 $\mathrm{h}$ after challenge there was no difference in TEER and capacitance between control and LPS-challenged cells. The addition of prednisolone to the LPS challenge did not prevent the decrease of TEER until $10 \mathrm{~h}$, but then increased TEER at $15 \mathrm{~h}$ after challenge $(P<0.0001$ at $15-30 \mathrm{~h})$. The capacitance was not affected by the combination of prednisolone and LPS. The addition of a low dosage $(0.25 \mathrm{mg} / \mathrm{mL})$ of meloxicam to the LPS treatment did not change LPS effects on TEER and capacitance at any time point. All other NSAID reduced TEER of LPS-challenged cells at $5 \mathrm{~h}$ after treatment compared with LPS-only challenged cells $(P<0.01)$. The capacitance of cells challenged with LPS and 0.75 $\mathrm{mg} / \mathrm{mL}$ meloxicam was reduced at $5 \mathrm{~h}$, with celecoxib at $10 \mathrm{~h}$ after treatment in comparison to control cells $(P$ $=0.033$ and 0.023 , respectively) but recovered at later time points. The addition of ketoprofen, diclofenac, or flunixin to the LPS challenge did not affect the capacitance in comparison to control. After $10 \mathrm{~h}$, ketoprofen and meloxicam at $0.75 \mathrm{mg} / \mathrm{mL}$ increased TEER compared with cells challenged with LPS only $(P=0.001$ and 0.044 , respectively). Conversely, other NSAID did not affect the reduction of TEER by LPS after $10 \mathrm{~h}$ challenge. At $15 \mathrm{~h}$ after treatment, TEER of cells challenged with LPS and ketoprofen or flunixin meglumine was significantly higher than cells challenged with LPS only $(P=0.001$ and $=0.042$, respectively $)$. The addition of celecoxib to the LPS challenge avoided the recovery of TEER within the $30 \mathrm{~h}$ of experiment $(P<$ 0.0001).

Results of NSAID treatment with the same amount of molecules with additional LPS challenge are shown in Figure 4 . The $4 \mathrm{~m} M$ concentration corresponds to higher concentrations than the dosages that were used in the other experiment based on recommendations to in vivo administration, except for ketoprofen. At $4 \mathrm{~m} M$ all NSAID decreased $(P<0.05)$ the TEER within 5 $\mathrm{h}$ after challenge compared with LPS-only treatment. The capacitance at $5 \mathrm{~h}$ was only affected (increased; $P$
$=0.001$ ) by diclofenac and did not recover throughout the entire experiment after this treatment. At $10 \mathrm{~h}$ the capacitance was reduced by the challenge with LPS and flunixin meglumine or meloxicam in comparison to controls $(P=0.008$ and 0.009 , respectively). At this time the TEER after treatment with flunixin-meglumin and meloxicam recovered to values of LPS-only challenged cells; however, at that time the TEER was even higher with the addition of ketoprofen compared with LPS only $(P<0.0001)$. After $30 \mathrm{~h}$, TEER was recovered with all treatments (LPS with or without $4 \mathrm{mM}$ of NSAID) except with diclofenac.

\section{TNF-a mRNA Abundance}

Results of the gene expression $(\Delta \mathrm{Ct})$ of TNF- $\alpha$ analyzed in cultured MEC are presented in Figure 5. The relative mRNA abundance of TNF- $\alpha$ was upregulated in cells challenged for $6 \mathrm{~h}$ with LPS $(1.0 \mu \mathrm{g} / \mathrm{mL})$ or with diclofenac $4 \mathrm{~m} M$ compared with negative controls (without LPS). In cells that received flunixin meglumine $(1.0 \mathrm{mg} / \mathrm{mL}$ and $4 \mathrm{mM})$, diclofenac $(0.75 \mathrm{mg} / \mathrm{mL}$ and $4 \mathrm{mM})$ or celecoxib $(0.05 \mathrm{mg} / \mathrm{mL})$, with or without LPS challenge, mRNA abundance of TNF- $\alpha$ was not affected.

\section{Cell Viability}

Results of the cell viability of MEC are represented in Figure 6. Meloxicam and diclofenac (at $0.75 \mathrm{mg} /$ $\mathrm{mL}$ and at $4 \mathrm{mM})$ reduced cell viability $(P=0.0004$, $<0.0001,0.0003$, and $<0.0001$, respectively) whereas LPS, ketoprofen $(1.25 \mathrm{mg} / \mathrm{mL}$ or $4 \mathrm{mM})$, flunixin meglumine $(1.0 \mathrm{mg} / \mathrm{mL}$ or $4 \mathrm{mM})$, meloxicam $0.25 \mathrm{mg} /$ $\mathrm{mL}$ or celecoxib $0.05 \mathrm{mg} / \mathrm{mL}$ did not change cell viability compared with negative controls. Addition of LPS challenge reduced the cell viability compared with treatments with the respective NSAID alone in the higher concentrations.

\section{DISCUSSION}

Cultured primary bovine MEC have been previously shown to mirror the mammary gland barrier function by formation of a cell monolayer and formation of tight junctions between cells (Wellnitz et al., 2016). Therefore, this model was used to investigate effects of NSAID on the blood-milk barrier function and integrity. Experiments were performed with cells from 3 cows to consider the biological variation between individual animals. The measurement of the TEER, which is inversely proportional to the barrier permeability (Berkes et al., 2003) and dependent of the integrity of tight junctions and cell viability (Wellnitz et al., 2016), 

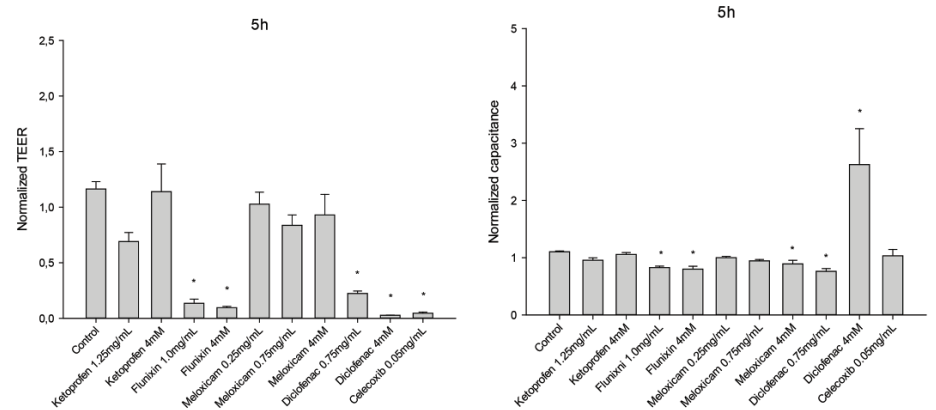

$10 \mathrm{~h}$

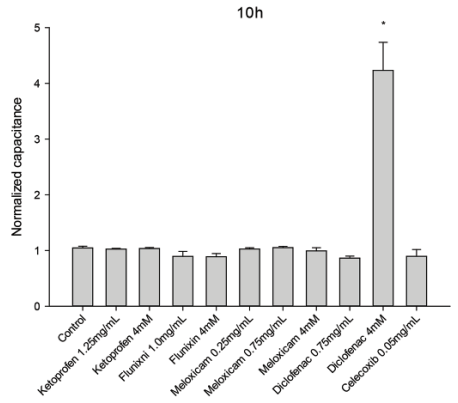

$15 \mathrm{~h}$
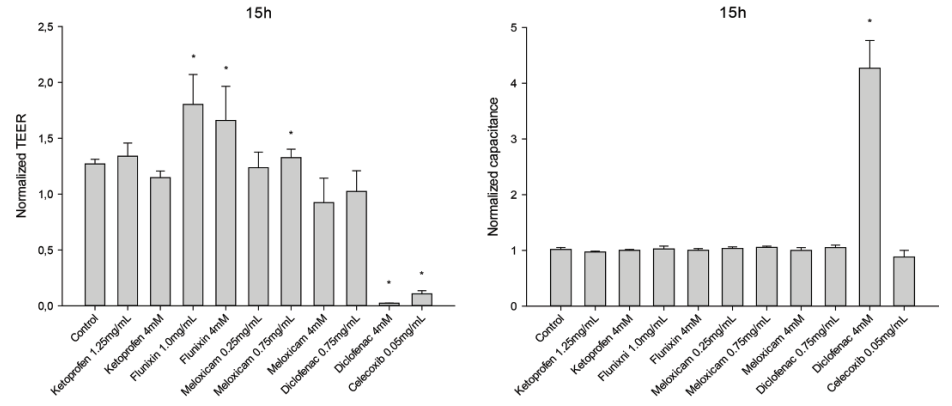

$20 \mathrm{~h}$
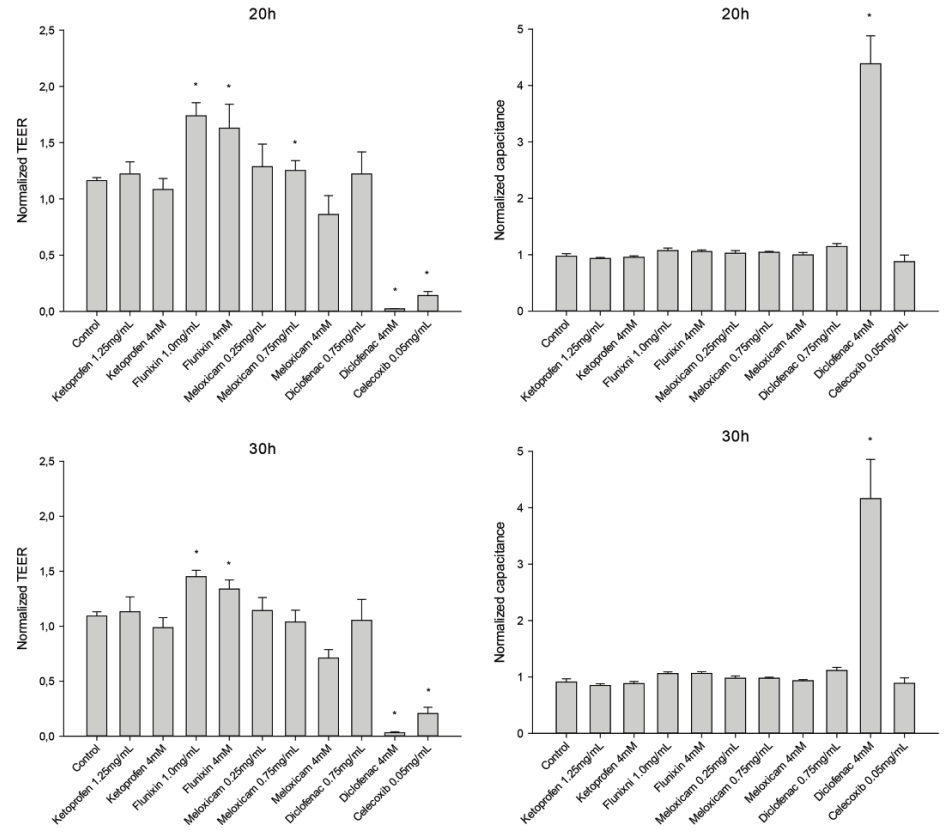

Figure 2. Transepithelial electrical resistance (TEER; $\left.\Omega / \mathrm{cm}^{2}\right)$ and capacitance $\left(\mu \mathrm{F} / \mathrm{cm}^{2}\right)$ of cells (mean \pm SEM) treated with ketoprofen, flunixin meglumine (flunixin), meloxicam, diclofenac, and celecoxib at a calculated concentration from the recommended dosage and the same amount of molecules $(4 \mathrm{mM})$ for $5,10,15,20$, and $30 \mathrm{~h}$, respectively. Data are normalized by calculating the ratio relative to the measurement of the control before treatment $(0 \mathrm{~h}) .{ }^{*}$ indicates significant difference $(P<0.05)$ from control (medium only). Error bars represent SEM. 



Figure 3. Transepithelial electrical resistance (TEER; $\Omega / \mathrm{cm}^{2}$ ) and capacitance $\left(\mu \mathrm{F} / \mathrm{cm}^{2}\right)$ of cells (mean \pm SEM) treated with prednisolone (pred), ketoprofen (ket), flunixin meglumine (fluni), meloxicam (mel), diclofenac (diclo), and celecoxib (cel) at a calculated concentration from the recommended dosage for $5,10,15,20$, and $30 \mathrm{~h}$, respectively. Data are normalized by calculating the ratio relative to the measurement of the control before treatment $(0 \mathrm{~h}) . *$ indicates significant differences $(P<0.05)$ from control (medium only); \# indicates significant differences from LPS $1.0 \mu \mathrm{g} / \mathrm{mL}$. Error bars represent SEM. 



Figure 4. Transepithelial electrical resistance (TEER; $\Omega / \mathrm{cm}^{2}$ ) and capacitance $\left(\mu \mathrm{F} / \mathrm{cm}^{2}\right.$ ) of cells (mean \pm SEM) treated with ketoprofen (ket), flunixin meglumine (fluni), meloxicam (mel), and diclofenac (diclo) at the same amount of molecules (4 $\mathrm{m} M)$ for 5, 10, 15, 20, and 30 h, respectively. Data are normalized by calculating the ratio of TEER relative to the measurement of the control before treatment $(0 \mathrm{~h}) . *$ indicates significant differences $(P<0.05)$ from control (medium only); \# indicates significant differences from LPS $1.0 \mu \mathrm{g} / \mathrm{mL}$. Error bars represent SEM. 


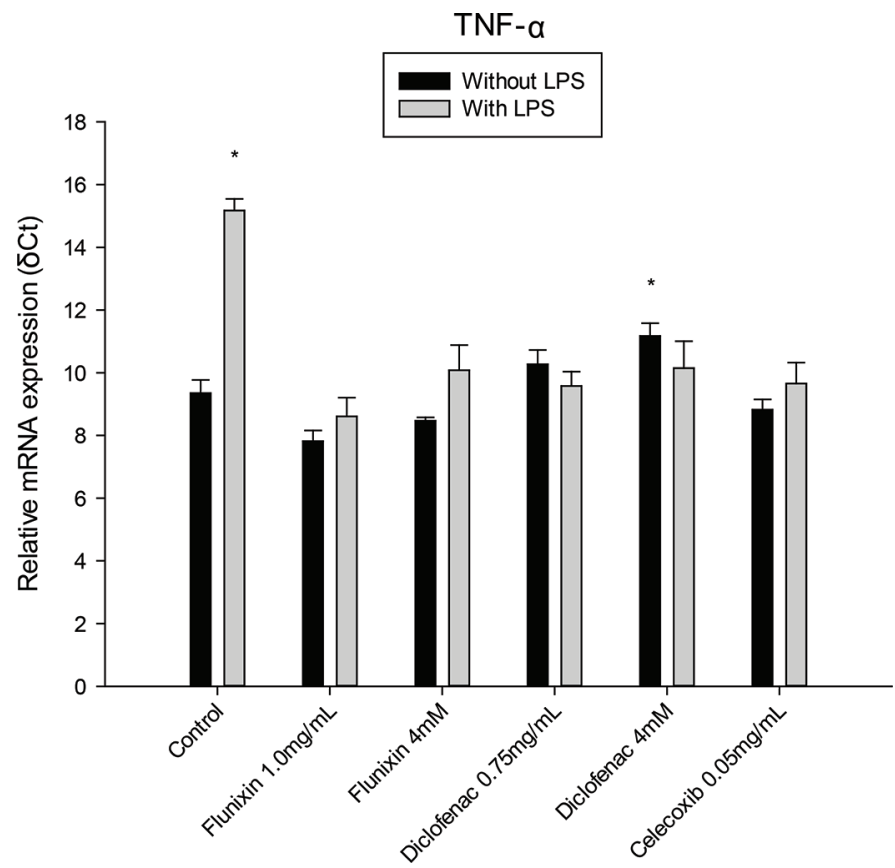

Figure 5. Relative mRNA abundance $[\Delta$ threshold cycle $(\mathrm{Ct})$; mean $\pm \mathrm{SEM}]$ of tumor necrosis factor $\alpha(\mathrm{TNF}-\alpha)$ in primary bovine epithelial mammary cells at $6 \mathrm{~h}$ postchallenge with LPS at a concentration of $1.0 \mu \mathrm{g} / \mathrm{mL}$ with (gray bars) or without (black bars) nonsteroidal anti-inflammatory drugs [NSAID; flunixin meglumine (flunixin), diclofenac, and celecoxib] treatment. $*$ indicates differences $(P$ $<0.05$ ) between control (without NSAID with or without additional LPS challenge) and treatment.

permitted the investigation of the substance-specific influence on the epithelial barrier.

Cells challenged with $1.0 \mu \mathrm{g} / \mathrm{mL}$ LPS showed an opening of the formed barrier characterized by a decrease in TEER which was in accordance to previous studies (Wellnitz et al., 2016). Opening of the barrier during inflammation of the mammary gland permits the transfer of blood components, such as leucocytes or antibodies, from blood to milk, facilitating the combat against involved pathogens (Burton and Erskine, 2003). However, this opening is also responsible for a transfer of components that do not necessarily contribute to the immune response from blood through the defective barrier but leading to changes in milk composition (Lehmann et al., 2013). Glucocorticoids are known to protect the blood-milk barrier during mastitis (Wellnitz et al., 2014; Wall et al., 2016) and, therefore, prednisolone was used as a positive control for barrier closure. It caused a faster recovery to normal barrier function than observed after challenge with LPS only. However, immunosuppression and inhibition of the barrier opening by glucocorticoids are not beneficial for the elimination of pathogens. The NSAID could be an alternative to glucocorticoids in local application by reducing symptoms of inflammation during mastitis without immunosuppression, and by inducing a faster stabilization of the blood-milk barrier opening in response to pathogens. It has to be taken into account that the present study was performed with LPS from gram-negative $E$. coli bacteria. Infection with these bacteria induces usually severe mastitis. Mastitis induced by gram-positive bacteria leads mostly to a less severe outcome and a less pronounced opening of the blood-milk barrier (Wellnitz et al., 2013), and the effect of NSAID on the blood-milk barrier could be less crucial.

The measurement of the cell viability was performed to investigate potential tissue irritating effects of NSAID in the mammary gland. Only diclofenac and meloxicam without LPS reduced the cell viability indicating tissue toxic effects. The combination of the studied NSAID in the selected concentrations with LPS induced a more pronounced decrease in cell viability than NSAID or LPS alone (although not in all concentrations). Günther et al. (2009) showed that during experimentally induced infection with $E$. coli, local reaction of the MEC was important in the combat against pathogens due to an upregulation of the synthesis of bactericidal substances such as $\beta$-defensin. Therefore, we hypothesize that the NSAID have an immunosuppressing effect on

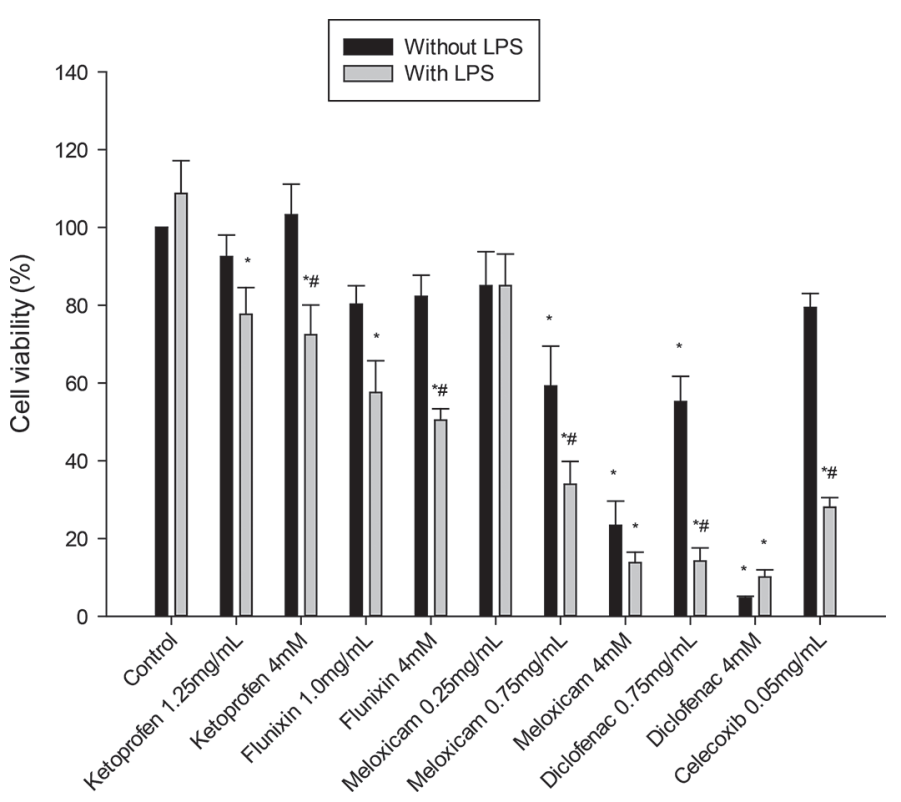

Figure 6. Cell viability ( $\% \pm \mathrm{SEM}$ ) compared with control (medium only). Treatments [ketoprofen, flunixin meglumine (flunixin), meloxicam, diclofenac, and celecoxib] are represented with (gray bars) or without (black bars) LPS. * indicates significant differences $(P<0.05)$ from control without nonsteroidal anti-inflammatory drug (NSAID) treatment; \# indicates significant differences $(P<0.05)$ within treatment with the same NSAID with and without additional LPS challenge. 
the MEC, which can alter the defense against LPS and reduce the survival rate of cells.

Meloxicam is a COX-2 selective NSAID used as supportive therapy during dairy cow mastitis, usually administrated systemically (McDougall et al., 2009). The COX-2 selectivity is a novelty to fight against side effects by NSAID, such as gastro-intestinal disorders, but not renal injuries or cardiovascular problems (Kawada et al., 2012). In a low dosage $(0.25 \mathrm{mg} / \mathrm{mL})$ meloxicam had no effect on cell viability and on TEER, including no improvement of the barrier recovery after LPS challenge. It was shown before that this low dosage does not reduce pro-inflammatory cytokine expression during LPS challenge in MEC (Caldeira et al., 2019). However, meloxicam at a higher concentration $(0.75 \mathrm{mg} / \mathrm{mL})$ reduced the cell viability and induced a more pronounced reduction of TEER by LPS but this was followed by a faster recovery compared with the challenge with LPS only. This clearly shows the dose dependency of meloxicam effects. The nonselective NSAID ketoprofen and flunixin meglumine are, as meloxicam, used for mastitis treatment in dairy cows by systemic administration. The treatment of MEC with these NSAID did not affect the cell viability, although they reduced the capacitance of cells, indicating that the cells need more time to recover to a normal morphology. As with meloxicam, ketoprofen and flunixin meglumine induced a more pronounced impairment of the barrier by LPS followed by a faster recovery, which is in accordance to in vivo studies were intramammary ketoprofen protected the blood-milk barrier during bovine mastitis (Dan et al., 2018). Blikslager and Gonzalez (2018) showed that flunixin meglumine did not allow the recovery of the intestinal epithelial barrier after injury, whereas meloxicam, a COX-2 selective NSAID did. The authors hypothesized that the COX-2 selectivity from several NSAID allows the production of reparative prostanoids by COX-1 because they could not detect histological damage by flunixin meglumine and suggested a delayed tight junction recovery. This uninhibited prostanoid production due to COX-2 selectivity may be the reason why meloxicam showed a similar recovery of TEER although it killed more cells than flunixin meglumine or ketoprofen in the present study. However, in the mammary gland nonselective NSAID may be of advantage compared with COX-2 selective NSAID due to a lower cell irritation, although these effects are dose dependent.

Diclofenac is a nonselective NSAID, in contrast to celecoxib, which is a COX-2 selective NSAID. Both NSAID seem to irritate mammary tissue as they reduced the cell viability even in lower concentrations. Together with LPS they pronounced the reduction of
TEER and delayed the recovery of the barrier. Cells can fill holes in the cell layer that are developed due to dead cells, by flattening and sending cell projections (Gookin et al., 2003). However, after diclofenac and celecoxib treatment the dead cell proportion was obviously too high to recover the barrier.

The capacitance of the cells challenged with LPS and treated with high dosage of flunixin meglumine or meloxicam, or low dosage of diclofenac or celecoxib, was reduced in comparison to control cells, indicating a change in the cell morphology. The NSAID at higher concentrations seem to induce irritation of mammary cells followed by increased barrier permeability. It must be expected that this irritation could also be observed in the mammary gland in vivo using an inappropriate dosage. After the treatment of cells with the high dosage of $4 \mathrm{~m} M$ diclofenac, the capacitance increased rapidly to the same range than before cells were attached to the transwell-insert and there was no recovery of TEER. We assume that this was due to cell detachment, as the detachment of cells from the surface was shown to induce a massive increase in capacitance before (Heijink et al., 2010). This detachment is probably due to the massive cell death, as shown by the cell viability, which decreased dramatically after addition of $4 \mathrm{mM}$ diclofenac with and without LPS. Therefore, diclofenac does not seem to be a suitable NSAID for treatment in dairy cows.

Recommended dosages of commercially available NSAID products are usually based on clinical studies. The tested NSAID have different chemical structures, and they are supposed to have different cellular effects related to different preferences of binding to COX subtypes. To visualize these differences at their molar levels we also tested the effects of the NSAID by using the same number of molecules $\left(4 \mathrm{~m} M=24 \times 10^{23} \mathrm{~mol}-\right.$ ecules $/ \mathrm{mL}$ ). This corresponds to higher concentrations than the dosages that were used based on suggestions to in vivo administration, except for ketoprofen. With the same number of molecules, the NSAID showed differences in efficiency and toxicity. Ketoprofen was the only NSAID that induced a recovery of TEER. All other NSAID at the same molar concentration did not accelerate the TEER recovery and caused reduction of cell viability during the immune response. This clearly shows that similar effects on the blood-milk barrier are induced by different amounts of molecules of the investigated NSAID. In human gastric epithelia the toxicity of NSAID was shown to be dependent on the COX-pathway production of prostaglandin inhibition. However, it was also discussed to be due to the topical activity of the substance, which is dependent of their acidity (Bjarnason, 2013). In our study, the effect of 
NSAID at the same molecular quantity on cell viability and on TEER and capacitance may be linked to the pKa of those NSAID. Indeed, pKa from meloxicam and diclofenac found in literature are in the same range and are lower than those of ketoprofen or flunixin meglumine, which is in accordance with the effects seen on cell viability and on TEER. Additionally, COXselectivity proved its importance by intestinal barrier recovery after injury (Gookin et al., 2003; Blikslager and Gonzalez, 2018) and, in our study, addition of COX-2 selective meloxicam improved the recovery of the barrier more than the nonselective diclofenac or flunixin meglumine, whereas the cell viability was similar or reduced.

All NSAID at the used dosages prevented the increase of TNF- $\alpha$ mRNA expression by LPS challenge in MEC compared with the controls shown in this study or before (Dan et al., 2018; Caldeira et al., 2019). This indicates that a treatment with NSAID during LPS challenge reduces the induced inflammation. However, in the present study this effect did not avoid the barrier opening, although TNF- $\alpha$ is known to increase the permeability of the human intestinal epithelial barrier (Al-Sadi et al., 2009).

\section{CONCLUSIONS}

Our study shows that different NSAID at specific dosages do not prevent the mammary epithelial barrier opening during LPS challenge but can improve the barrier recovery in vitro. The anti-inflammatory effect of the different NSAID shown by inhibition of the increase of TNF- $\alpha$ mRNA expression likely improves the wellbeing of treated cows. Diclofenac and celecoxib seem to irritate the cells much more than the other NSAID and the recovery of the barrier seems to be influenced by inflammation. Furthermore, the nonselective COX inhibition versus the COX-2 selective inhibition seems to play a role in the barrier recovery after cell degradation, although both groups showed an improvement of the barrier recovery. The results of this study should be taken into account if NSAID are used in dairy cow mastitis treatment, specifically if a local intramammary administration is considered. An in vivo treatment of mastitis with NSAID could be of advantage compared with steroidal anti-inflammatory treatment because the transfer of immunoglobulins through the opened blood-milk barrier in the beginning of mastitis is not inhibited but may prevent a longer lasting exchange of components between blood and milk. Furthermore, this study clearly shows that not only the dosage influences the effects on mammary gland cells, but also the NSAID type.

\section{ACKNOWLEDGMENTS}

We thank Claudine Morel (Veterinary Physiology, Vetsuisse Faculty, University of Bern, Switzerland) for her support in the laboratory analyses. The authors confirm that they have no conflicts of interest.

\section{REFERENCES}

Afshar, S., E. Salimi, A. Fazelkhah, K. Braasch, N. Mishra, M. Butler, D. J. Thomson, and G. E. Bridges. 2019. Progression of change in membrane capacitance and cytoplasm conductivity of cells during controlled starvation using dual-frequency DEP cytometry. Anal. Chim. Acta 1059:59-67. https://doi.org/10.1016/j.aca.2019 .01.046.

Al-Sadi, R., M. Boivin, and T. Ma. 2009. Mechanism of cytokine modulation of epithelial tight junction barrier. Front. Biosci. (Landmark Ed) 14:2765-2778. https://doi.org/10.2741/3413.

Banting, A., S. Banting, K. Heinonen, and K. Mustonen. 2008. Efficacy of oral and parenteral ketoprofen in lactating cows with endotoxin-induced acute mastitis. Vet. Rec. 163:506-509. https:// doi.org/10.1136/vr.163.17.506.

Benson, K., S. Cramer, and H.-J. Galla. 2013. Impedance-based cell monitoring: Barrier properties and beyond. Fluids Barriers CNS 10:5. https://doi.org/10.1186/2045-8118-10-5.

Berkes, J., V. K. Viswanathan, S. D. Savkovic, and G. Hecht. 2003. Intestinal epithelial responses to enteric pathogens: Effects on the tight junction barrier, ion transport, and inflammation. Gut 52:439-451. https://doi.org/10.1136/gut.52.3.439.

Bjarnason, I. 2013. Gastrointestinal safety of NSAIDs and over-thecounter analgesics. Int. J. Clin. Pract. Suppl. 67:37-42. https:// doi.org/10.1111/ijcp.12048

Blikslager, A., and L. Gonzalez. 2018. Equine intestinal mucosal pathobiology. Annu. Rev. Anim. Biosci. 6:157-175. https://doi .org/10.1146/annurev-animal-030117-014748.

Bruckmaier, R. M., C. E. Ontsouka, and J. W. Blum. 2004. Fractionized milk composition in dairy cows with subclinical mastitis. Vet. Med. Czech. 49:283-290. https://doi.org/10.17221/5706 -VETMED.

Bruckmaier, R. M., and O. Wellnitz. 2017. Pathogen-specific immune response and changes in the blood-milk barrier of the bovine mammary gland. J. Anim. Sci. 95:5720-5728. https://doi.org/10.2527/ jas2017.1845.

Burton, J. L., and R. J. Erskine. 2003. Immunity and mastitis. Some new ideas for an old disease. Vet. Clin. North Am. Food Anim. Pract. 19:1-45. https://doi.org/10.1016/S0749-0720(02)00073-7.

Caldeira, M. O., R. M. Bruckmaier, and O. Wellnitz. 2019. Meloxicam affects the inflammatory responses of bovine mammary epithelial cells. J. Dairy Sci. 102:10277-10290. https://doi.org/10.3168/jds 2019-16630.

Dan, D., R. M. Bruckmaier, and O. Wellnitz. 2018. Ketoprofen affects the mammary immune response in dairy cows in vivo and in vitro. J. Dairy Sci. 101:11321-11329. https://doi.org/10.3168/jds .2018-15034.

Díaz-González, F., and F. Sánchez-Madrid. 2015. NSAIDs: Learning new tricks from old drugs. Eur. J. Immunol. 45:679-686. https:// doi.org/10.1002/eji.201445222.

Gookin, J. L., J. A. Galanko, A. T. Blikslager, and R. A. Argenzio. 2003. PG-mediated closure of paracellular pathway and not restitution is the primary determinant of barrier recovery in acutely injured porcine ileum. Am. J. Physiol. Gastrointest. Liver Physiol. 285:G967-G979. https://doi.org/10.1152/ajpgi.00532.2002.

Griesbeck-Zilch, B., H. H. D. Meyer, Ch. Kühn, M. Schwerin, and O. Wellnitz. 2008. Staphylococcus aureus and Escherichia coli cause deviating expression profiles of cytokines and lactoferrin messenger ribonucleic acid in mammary epithelial cells. J. Dairy Sci. 91:2215-2224. https://doi.org/10.3168/jds.2007-0752. 
Günther, J., D. Koczan, W. Yang, G. Nürnberg, D. Repsilber, H. J. Schuberth, Z. Park, N. Maqbool, A. Molenaar, and H. M. Seyfert. 2009. Assessment of the immune capacity of mammary epithelial cells: Comparison with mammary tissue after challenge with Escherichia coli. Vet. Res. 40:31. https://doi.org/10.1051/vetres/ 2009014.

Heijink, I. H., S. M. Brandenburg, J. A. Noordhoek, D. S. Postma, D. J. Slebos, and A. J. van Oosterhout. 2010. Characterisation of cell adhesion in airway epithelial cell types using electric cell-substrate impedance sensing. Eur. Respir. J. 35:894-903. https://doi.org/10 $.1183 / 09031936.00065809$

Kawada, N., T. Moriyama, H. Kitamura, R. Yamamoto, Y. Furumatsu, I. Matsui, Y. Takabatake, Y. Nagasawa, E. Imai, C. S. Wilcox, H. Rakugi, and Y. Isaka. 2012. Towards developing new strategies to reduce the adverse side-effects of nonsteroidal anti-inflammatory drugs. Clin. Exp. Nephrol. 16:25-29. https://doi.org/10.1007/ s10157-011-0492-3.

Kayitsinga, J., R. L. Schewe, G. A. Contreras, and R. J. Erskine. 2017. Antimicrobial treatment of clinical mastitis in the eastern United States: The influence of dairy farmers' mastitis management and treatment behavior and attitudes. J. Dairy Sci. 100:1388-1407. https://doi.org/10.3168/jds.2016-11708.

Lehmann, M., O. Wellnitz, and R. M. Bruckmaier. 2013. Concomitant lipopolysaccharide-induced transfer of blood-derived components including immunoglobulins into milk. J. Dairy Sci. 96:889-896. https://doi.org/10.3168/jds.2012-5410.

Llorens, O., J. J. Perez, A. Palomer, and D. Mauleon. 2002. Differential binding mode of diverse cyclooxygenase inhibitors. J. Mol. Graph. Model. 20:359-371. https://doi.org/10.1016/S1093 $-3263(01) 00135-8$

McDougall, S., M. A. Bryan, and R. M. Tiddy. 2009. Effect of treatment with the nonsteroidal anti-inflammatory meloxicam on milk production, somatic cell count, probability of re-treatment, and culling of dairy cows with mild clinical mastitis. J. Dairy Sci. 92:4421-4431. https://doi.org/10.3168/jds.2009-2284.

Molony, V., J. E. Kent, B. D. Hosie, and M. J. Graham. 1997. Reduction in pain suffered by lambs at castration. Vet. J. 153:205-213. https://doi.org/10.1016/S1090-0233(97)80041-X.

Srinivasan, B., A. R. Kolli, M. B. Esch, H. E. Abaci, M. L. Shuler, and J. J. Hickman. 2015. TEER measurement techniques for in vitro barrier model systems. J. Lab. Autom. 20:107-126. https://doi .org/10.1177/2211068214561025.
Wall, S. K., L. E. Hernández-Castellano, A. Ahmadpour, R. M. Bruckmaier, and O. Wellnitz. 2016. Differential glucocorticoid-induced closure of the blood-milk barrier during lipopolysaccharide- and lipoteichoic acid-induced mastitis in dairy cows. J. Dairy Sci. 99:7544-7553. https://doi.org/10.3168/jds.2016-11093.

Wellnitz, O., E. T. Arnold, M. Lehmann, and R. M. Bruckmaier. 2013. Short communication: Differential immunoglobulin transfer during mastitis challenge by pathogen-specific components. J. Dairy Sci 96:1681-1684. https://doi.org/10.3168/jds.2012-6150.

Wellnitz, O., and R. M. Bruckmaier. 2012. The innate immune response of the bovine mammary gland to bacterial infection. Vet. J. 192:148-152. https://doi.org/10.1016/j.tvjl.2011.09.013.

Wellnitz, O., and D. E. Kerr. 2004. Cryopreserved bovine mammary cells to model epithelial response to infection. Vet. Immunol. Immunopathol. 101:191-202. https://doi.org/10.1016/j.vetimm.2004 .04.019.

Wellnitz, O., S. K. Wall, M. Saudenova, and R. M. Bruckmaier. 2014. Effect of intramammary administration of prednisolone on the blood-milk barrier during the immune response of the mammary gland to lipopolysaccharide. Am. J. Vet. Res. 75:595-601. https:// doi.org/10.2460/ajvr.75.6.595.

Wellnitz, O., C. Zbinden, X. Huang, and R. M. Bruckmaier. 2016 Short communication: Differential loss of bovine mammary epithelial barrier integrity in response to lipopolysaccharide and lipoteichoic acid. J. Dairy Sci. 99:4851-4856. https://doi.org/10.3168/ jds.2016-10927.

Wellnitz, O., C. Zbinden, J. Lüttgenau, H. Bollwein, and R. M. Bruckmaier. 2015. Different chronological patterns of appearance of blood derived milk components during mastitis indicate different mechanisms of transfer from blood into milk. J. Dairy Res. 82:322327. https://doi.org/10.1017/S0022029915000345.

Yeiser, E. E., K. E. Leslie, M. L. McGilliard, and C. S. PeterssonWolfe. 2012. The effects of experimentally induced Escherichia coli mastitis and flunixin meglumine administration on activity measures, feed intake, and milk parameters. J. Dairy Sci. 95:49394949. https://doi.org/10.3168/jds.2011-5064.

\section{ORCIDS}

R. M. Bruckmaier (ㄴ) https://orcid.org/0000-0002-9374-5890

O. Wellnitz @ https://orcid.org/0000-0002-5817-3428 